Journal of Biomedical

Materials Research

WILEY

Part B: Applied Biomaterials

\title{
Cardiac tissue regeneration: a preliminary study on carbon- based nanotubes gelatin scaffold
}

\begin{tabular}{|c|c|}
\hline Journal: & Journal of Biomedical Materials Research: Part B - Applied Biomaterials \\
\hline Manuscript ID & JBMR-B-17-0490 \\
\hline Wiley - Manuscript type: & Original Research Report \\
\hline Date Submitted by the Author: & 25-Jul-2017 \\
\hline Complete List of Authors: & $\begin{array}{l}\text { Cabiati, Manuela; Istituto di Fisiologia Clinica CNR, } \\
\text { Vozzi, Federico; CNR, Institute of Clinical Physiology, Pisa } \\
\text { Gemma, Federica; Istituto di Fisiologia Clinica CNR } \\
\text { Montemurro, Francesca; University of Pisa, Research Center "E. Piaggio" } \\
\text { De Maria, Carmelo; University of Pisa, Research Center E. Piaggio } \\
\text { Vozzi, Giovanni; Interdepartmental Research Center "E. Piaggio", Faculty of } \\
\text { Engineering -University of Pisa } \\
\text { Domenici, Claudio; CNR, Institute of Clinical Physiology, Pisa } \\
\text { Del Ry, Silvia; Istituto di Fisiologia Clinica CNR }\end{array}$ \\
\hline Keywords: & $\begin{array}{l}\text { tissue engineering, scaffolds, Single Walled carbon nanotubes, trans- } \\
\text { retinoic acid, natriuretic peptides/endothelin system }\end{array}$ \\
\hline
\end{tabular}


1

2

3

4

5

6

7

8

9

10

11

12

13

14

15

16

17

18

19

20

21

22

23

24

25

26

27

28

29

30

31

32

33

34

35

36

37

38

39

40

41

42

43

44

45

46

47

48

49

50

51

52

53

54

55

56

57

58

59

60

Cardiac tissue regeneration: a preliminary study on carbon-based nanotubes gelatin scaffold

Manuela Cabiati ${ }^{* 1}$, Federico Vozzi ${ }^{* 1}$, Federica Gemma ${ }^{1}$, Francesca Montemurro ${ }^{2}$, Carmelo De Maria $^{2}$, Giovanni Vozzi ${ }^{2}$, Claudio Domenici ${ }^{1}$, Silvia Del Ry ${ }^{1}$

*contributed equally to this work

${ }^{1}$ CNR Institute of Clinical Physiology, Pisa, Italy

${ }^{2}$ Interdepartmental Research Centre "E. Piaggio", University of Pisa, Italy

Corresponding author:

Dr. Cabiati Manuela

CNR Institute of Clinical Physiology,

Via Giuseppe Moruzzi 1, 56124 Pisa - Italy

Tel.: 050 3153551- Fax 0503152166

e-mail: manuela.cabiati@ifc.cnr.it

Running Heads: Carbon-based nanotubes gelatin scaffold for heart regeneration

John Wiley \& Sons, Inc. 


\begin{abstract}
Aim of this study was the set-up of gelatin and carbon nanotubes (CNTs) scaffolds for cardiac tissue engineering applications. Gelatin-based scaffolds and SingleWalled CNTs $(0.3 \%$ and $0.9 \%)$, cross-linked with genipin $0.2 \%$, were prepared. H9c2 cell line was cultured for 10 days in culture medium, supplemented with $10 \%$ of FBS $\left(\mathrm{C}_{10 \%}\right)$. Myoblast differentiation was induced by FBS reduction to $1 \%\left(\mathrm{C}_{1 \%}\right)$, while cardiac phenotype by stimulation with $50 \mathrm{nM}$ all trans-retinoic acid $\left(C_{R A}\right)$. Cell viability, citotoxicity, phenotype differentiation, immunohistochemical assay and RealTime PCR analysis were performed. Immunohystochemistry showed elongated myotubes in $\mathrm{C}_{1 \%}$, (skeletal phenotype) and round and multinucleated cells in $\mathrm{C}_{\mathrm{RA}}$ (cardiac phenotype), as confirmed by a significantly increased expression of Natriuretic Peptides (NP)-system in $\mathrm{C}_{\mathrm{RA}}$ with respect to $\mathrm{C}_{10 \%}$ and $\mathrm{C}_{1 \%}$ as well as of ET-A and ET-B receptors in parallel with a decreased ET-1. In SWCNTs cell viability was similar both at $0.3 \%$ and $0.9 \%$; NP and ET-systems expression decreased in $\mathrm{SWCNT}_{0.3 \%}$ and $\mathrm{SWCNT}_{0.9 \%}$ with respect to $\mathrm{C}_{10 \%}$, as well as $\mathrm{CX}-43$ mRNA $(\mathrm{p}<0.01)$, mainly due to a lacking of complete differentiation in cardiac phenotype during these few days. Although further analyses on novel biomaterials are necessary, these results represent a useful starting point to develop new scaffold-based biomaterials.
\end{abstract}

Keywords: tissue engineering, scaffolds, SingleWalled carbon nanotubes, trans-retinoic acid, natriuretic peptides, endothelin system 


\section{INTRODUCTION}

Cardiovascular disease (CVD) remains the leading cause of death among European countries and in Italy it represents the $44 \%$ of all death among population. ${ }^{1}$ The clinical course of cardiovascular diseases, mainly heart failure (HF), is unpredictable and, often, patients with end-stage HF refractory to medical treatment required advanced specialized treatments, fluid removal procedures, experimental surgery or durable left ventricular assist device (LVAD) until the end-of-life. ${ }^{2}$ However, the only effective treatment is heart transplantation but due to the scarce supply of donor hearts, only few patients receive this procedure. ${ }^{3}$ To address this problem, current research has been directed towards cell-based therapies ${ }^{4}$ and cardiac tissue engineering. ${ }^{5}$ Cardiac tissue engineering is a multidisciplinary field that brings together the principles of cellular biology, material science and biomedical engineering for regenerative medicine development, providing force-producing heart muscle tissue that could be transplanted on injured hearts restoring their function. ${ }^{6}$ Cardiac tissue engineering is based on design of bioactive biomaterials, called scaffolds, usually seeded with cells and able to be used for in-situ cardiac repair through promoting vascularization or cell recruitment, survival and growth. ${ }^{7}$ Scaffolds are biodegradable structures with mechanical/electrical properties mimicking the native tissue, and can be manipulated into various shapes or sizes. ${ }^{8}$ However, a great number of injectable scaffolds developed for myocardial applications are non-conductive, lack nanofibrous architectures on the submicrometer scale (10-100 $\mathrm{nm}$ in diameter) and are mechanically weaker than native heart tissues ${ }^{9}$ : for these reasons different materials have been identified to ameliorate scaffolds' properties. Among them, Carbon Nanotubes (CNTs) are certainly numbered as the most interesting ones being hypothetically the ideal material for a successful biomaterial in cardiac applications. The CNTs dimensions range from 1 to $100 \mathrm{~nm}$, showing high mechanical and electrical properties, low weight and either chemical and thermal stability. ${ }^{10}$ For cardiac tissue engineering, both single- and multi-walled CNT (SWCNTs and MWCNTs, respectively) are used to create scaffolds with a specific elastic modulus and electrical nature making them suitable as optimal interface with excitable cells, such as heart myocytes. The cardiomyocytes, interacting with 
CNT scaffolds, are able to modify their viability, proliferation, growth, maturation and electrophysiological properties. ${ }^{11,12}$

In the light of these observations, aim of this study was to set up gelatin-based CNT scaffolds for cardiac tissue engineering applications and to evaluate their biological properties in inducing phenotypic changes in an in-vitro experimental model of $\mathrm{H} 9 \mathrm{c} 2$ cell line.

\section{MATERIALS AND METHODS}

\section{Conductive scaffolds preparation}

Single walled nanotubes (SWCNTs) were sterilized under UV for 15 minutes and then used to prepare a solution in distilled water with a concentration of $0.75 \% \mathrm{w} / \mathrm{v}$. To increase dispersion of unsoluble nanotubes, $100 \mu \mathrm{L}$ of Tween 20 were added. The mixture was sonicated (Vibra Cell VC130, Sonics \& Materials Inc., Newton, USA) for 2 hours (5 minutes break every 30 minutes of sonication, $2 \mathrm{~W}$ power). For scaffold fabrication, a solution of porcine gelatin $5 \% \mathrm{w} / \mathrm{v}$ (Sigma Aldrich, St. Louis, MO, U.S.A) in distilled water was prepared. SWCNTs were added to gelatin solution to obtain samples at different concentration: $0.3 \%, 0.5 \%, 0.7 \%, 0.9 \%, 1.3 \% \mathrm{w} / \mathrm{w}$ per gelatin weight. Then, the cross-linker genipin (GP) $0.2 \% \mathrm{w} / \mathrm{v}$ was added to the gelatin-SWCNT mixture and each dispersion was then homogenized by sonication. At the end, $500 \mu \mathrm{L}$ of gelatinSWCNT were pipetted in a 12 -multiwell plate and incubated at $37^{\circ} \mathrm{C}$ for $48 \mathrm{~h}$. To complete the sterilization process, ethanol $70 \%$ was added in each well and the plate was placed at $4{ }^{\circ} \mathrm{C}$ for $24 \mathrm{~h}$, followed by several washes with PBS solution. Before cell seeding, the multiwell plate containing the scaffolds was exposed to UV lamp for 30 minutes.

\section{Mechanical characterization}

For mechanical and impedance tests, gelatin-SWCNT scaffolds were prepared with the previous protocol but solutions were casted in Petri dishes for 48 hours at room temperature. They were cut in a strip shape, hydrated for 8 minutes, to reach the swelling equilibrium and then they were subjected to tensile tests till break, with a deformation rate of $1 \% / \mathrm{min}$, using a uniaxial testing 
machine Zwick-Roell Z005 (Zwick GmbH \& Co, Germany). The tests were performed in triplicate. The elastic modulus was calculated from the slope of the first linear part of the stress-strain curve.

\section{Impedance tests}

Impedance was measured using $2 \mathrm{MHz}$ precision LCR meter Agilent E4890A (Agilent Technologies, Santa Clara CA, USA). Copper tape strips were attached to the end of each samples to plug in clamps of impedance analyzer. A total of 133 different frequencies were measured between $1 \mathrm{kHz}$ and $2 \mathrm{Mhz}$. The tests were performed in triplicate.

\section{Cell culture}

H9c2 rat cardiomyoblast cell line (ATCC-CRL-2522, Teddington, UK) were cultured in High Glucose DMEM (Dulbecco's Modified Eagle's Medium) supplemented with 10\% FBS (Foetal Bovine Serum), $2 \mathrm{mM}$ L-Glutamine, $100 \mu \mathrm{U} / \mathrm{mL}$ Penicillin, 10-1 $\mu \mathrm{U} / \mathrm{mL}$ Streptomycin and 2.5x10$1 \mu \mathrm{U} / \mathrm{mL}$ Amphotericin B. All these products were purchased at Sigma-Aldrich (St. Louis, MO, U.S.A.). Cells were cultured in $75 \mathrm{~cm}^{2}$ flasks at $37^{\circ} \mathrm{C}$ in a humidified atmosphere of $5 \% \mathrm{CO}_{2}$ changing medium every $2 / 3$ days and amplified until reached confluence.

\section{Cytotoxicity}

Each sample of gelatin-SWCNT scaffold was extracted at $37{ }^{\circ} \mathrm{C}$ for $24 \mathrm{~h}$ in $3 \mathrm{~mL}$ of DMEM complete medium, described above. Complete medium supplemented with 5\% DMSO was used as positive control. Cells cultured in standard medium were used as negative control.

Cells were seeded at confluence in 96-well plate and, once adhered, medium was changed with 200 $\mu \mathrm{l}$ of the extracted one (at least 6 wells). After exposure to the extract for $72 \mathrm{~h}$ at $37^{\circ} \mathrm{C}$, changes of cellular morphology were evaluated with AX70 light-reverted microscope (Olympus, Milan, Italy) and cell viability was tested by using Promega CellTiter Blue ${ }^{\circledR}$ (Madison, WI, USA). In each well $100 \mu \mathrm{l}$ of fresh new medium were added together with $10 \mu \mathrm{l}$ of reagent. After $150 \mathrm{~min}$, the Relative Fluorescent Unit (RFU) values were evaluated with spectrophotometer plate reader (579ex/584em) (BMG LabTech, Fluostar Omega, Ortemberg, Germany). Samples with a viability value of at least $70 \%$ were selected for the cell culture growth profile. 


\section{Cell growth}

Cells at confluence were washed with $5 \mathrm{ml}$ of PBS, detached by $3 \mathrm{ml}$ of Trypsin $[0.25 \%(\mathrm{w} / \mathrm{v})]$ and placed in contact with $12 \mathrm{ml}$ of fresh complete medium to deactivate enzyme action. H9c2 were counted with haemocytometer and seeded on the scaffolds at a cell density of $40 \%(56000$ cell $\left./ \mathrm{cm}^{2}\right)$. At well-defined times (1, 3, 7 days) medium cell culture wash changed. The experiment had a duration of 10 days.

\section{Differentiation protocol}

In order to evaluate the potential cardiac or myogenic differentiation process induced by SWCNTbased scaffolds, a differentiation protocol was applied. After cell seeding, control samples were divided as follows:

- negative control $\left(\mathrm{C}_{10 \%}\right)$ : cells with DMEM complete medium supplemented with $10 \% \mathrm{FBS}$;

- positive control $1\left(\mathrm{C}_{1 \%}\right)$ : cells with DMEM medium supplemented with $1 \% \mathrm{FBS}$, useful to evaluate potential myogenic differentiation;

- positive control $2\left(\mathrm{C}_{\mathrm{RA}}\right)$ : cells with DMEM medium supplemented with $1 \%$ FBS and $50 \mathrm{nM}$ retinoic acid, useful to evaluate potential cardiac differentiation.

At well-defined times (1, 3, 7 days) culture medium was changed. The experiment had a duration of 10 days.

\section{Immunohistochemical analysis}

Paraformaldehyde-fixed samples were treated for evaluation of Myogenin (for myogenic differentiation) and Myosin regulatory light chain 2 (MYL2, for cardiac differentiation). Myogenin was recognized by and anti-rat Myogenin (F5D) mouse primary antibody and, for analysis on scaffolds, a DAPI-conjugated secondary antibody (donkey anti-mouse IgG-DAPI) was used, while for controls, a FITC-conjugated secondary antibody (donkey anti-mouse IgG-FITC) was used. In the same way, MYL2 was identified by anti-rat MYL2 (C-17) goat primary antibody and, for analysis on scaffolds, a DAPI-conjugated secondary antibody (rabbit anti-goat IgG-DAPI) and, for controls, a TRITC-conjugated secondary antibody (rabbit anti-goat IgG-TRITC) were used. All the 
primary antibodies were purchased at Santa Cruz Biotechnology (Dallas, TX, USA) while secondary at ThermoFisher Scientific (Waltham, MA, USA). Samples were washed three times with PBS for $5 \mathrm{~min}$ and treated with $0.1 \%$ Triton in PBS for $2 \mathrm{~min}$ at room temperature to permeabilize cell membranes. Samples were left in 5\% BSA for $30 \mathrm{~min}$ and then treated with the primary antibody, $1: 50$ diluted in $1 \% \mathrm{BSA}$, for $1 \mathrm{~h}$ at $37^{\circ} \mathrm{C}$. Then, the secondary antibody $1: 100$ diluted in $1 \%$ BSA was added to the samples for 1 hat $37^{\circ} \mathrm{C}$. At the end of incubation, each sample was washed three times with PBS for 5 min. Finally, samples were analyzed at the fluorescence microscope (CX40, Olympus, Milan, Italy).

\section{Molecular biology analysis: from RNA extraction to Real-Time PCR}

Total RNA was extracted from H9c2 cell line by acid guanidinium thiocyanate-phenol-chloroform (TRI Reagent ${ }^{\circledR}$ Sigma Aldrich) following RNeasy Mini kit manufacturer’ instruction (Qiagen SpA, Milano, Italy) as previously described ${ }^{13}$; after re-suspension and lysis of the cells with insulin syringes to break the cell membrane and to allow acid guanidinium thiocyanate-phenol-chloroform to entry at intracellular level, samples were selective bound on a silica-based membrane and speeded on a microspin centrifuge. A specific high-salt buffer system allows RNA to bind to the RNeasy silica membrane and contaminants were washed out. High-quality RNA were then eluted in $50 \mu$ of RNAse free water. The total RNA concentration was determined in all samples by measuring the spectrophotometer absorbance at 260 and $280 \mathrm{~nm}$ (BioPhotometer Eppendorf, Milan, Italy) and calculated using the Beer-Lambert law, with expected values between 1.8-2.1. The RNA samples were stored at $-80{ }^{\circ} \mathrm{C}$ for use in gene expression studies.

First-strand cDNA was synthesized by IScript cDNA Synthesis Kit (Bio-Rad Laboratories Inc., Hercules, CA, USA), which uses the Moloney Murine Leukemia Virus (M-MuLV) reverse transcriptase, optimized for reliable cDNA synthesis over $1 \mu \mathrm{g}$ of total RNA as template. Reverse transcriptase reaction sequence consisted of incubation at $25^{\circ} \mathrm{C}$ for $5 \mathrm{~min}$, followed by three different cycles at $42^{\circ} \mathrm{C}$ for $30 \mathrm{~min}$ and $45-48^{\circ} \mathrm{C}$ for $10 \mathrm{~min}$, in order to better separate the strands. The reverse transcriptase enzyme was inactivated by heating to $85^{\circ} \mathrm{C}$ for $5 \mathrm{~min}$. The cDNA John Wiley \& Sons, Inc. 
samples obtained were placed on ice and stored at $4{ }^{\circ} \mathrm{C}$. Natriuretic peptide (atrial natriuretic peptide, ANP, B-type and C-type natriuretic peptides, BNP and CNP, together with their specific receptor, NPR-A, NPR-B and the clearance one NPR-C), endothelin system (prepro-ET-1 and receptors ET-A and ET-B) and Connexin (CX)-43 expression was determined by Real-time PCR, Real-Time PCR performed in duplicate on the Bio-Rad C1000 TM thermal cycler (CFX-96 RealTime PCR detection systems, Bio-Rad) as previously described. ${ }^{14}$ For monitoring cDNA amplification, a third-generation fluorophore, EvaGreen, was used (SsoFAST EvaGreen Supermix, Bio-Rad). Real-Time PCR was performed in a volume of $20 \mu \mathrm{l}$ per reaction, including $0.2 \mu \mathrm{M}$ of each primer (Sigma-Aldrich, St. Louis, MO, USA), samples, reagent and sterile $\mathrm{H}_{2} \mathrm{O}$. Since RealTime PCR efficiency is highly dependent on the primers used, their sequences were accurately selected and whenever possible, intron-spanning primers were selected to avoid amplification of genomic DNA. To better improve primers specificity, the regions of homology were checked and eluded as well as secondary structures leading to poor or no yield of the product was avoided. Amplification protocol started with $98{ }^{\circ} \mathrm{C}$ for $30 \mathrm{~s}$ followed by 40 cycles at $95{ }^{\circ} \mathrm{C}$ for $5 \mathrm{~s}$ and the optimal annealing temperature was assessed performing a gradient PCR; to verify amplification efficiency a standard curve obtained by scalar dilution of a cDNA pool (1:5, 1:25, 1:125, and 1:625), was generated. Efficiency was evaluated of $90-105 \%$ with a linear standard curve R2 coefficient $\geq 0.998$. To assess product specificity, amplicons were systematically checked by melting curve analysis. Melting curves were generated from $65^{\circ} \mathrm{C}$ to $95{ }^{\circ} \mathrm{C}$ with increments of 0.5 ${ }^{\circ} \mathrm{C} /$ cycle.

\section{Statistical methods}

In an effort to provide greater transparency of our results between research laboratories, this study was carried out to conform to the Minimum Information for publication of Quantitative Real-Time PCR Experiments (MIQE). ${ }^{15}$ Nine reference genes were tested and the GeNorm technology integrated in the Bio-Rad's CFX96 manager software (CFX-96 Real-Time PCR detection systems, Bio-Rad Laboratories Inc., Hercules, CA, USA) was used to establish the most stably expressed 
gene, as described by Vandesompele et al. ${ }^{16}$ Normalization of mRNA expression results was made by the geometric mean of the three most stably expressed genes. The relative quantification was performed by $\Delta \Delta \mathrm{Ct}$ method. When expression values were not normally distributed, the logarithmic transformation of data was used for statistical analysis. Differences between more than two independent groups were analyzed by Fisher's test after ANOVA. Differences between two independent groups were assessed by unpaired t-test. The results are expressed as mean \pm SEM and $p$-value was considered significant when $<0.05$. The association between different variables were assessed by linear regression. All data were analyzed by using Statview 5.0.1 software released for Windows Statistical (SAS Institute, Inc., Cary, NC, USA).

\section{RESULTS}

\section{Mechanical tests}

All the samples presented wet aspect, flexible behaviour and adhesive properties to flat surfaces, regardless the SWCNTs concentration. Mechanical test results clearly indicated an increase of the biomaterial stiffness as the SWCNTs concentration increases, with a Pearson coefficient of 0.97 (Fig. 1 a-c). As the elastic modulus, also the failure stress increases with the amount of CNTs: the failure stress spans from $139 \pm 11 \mathrm{kPa}$ of the pure gel to $428 \pm 13 \mathrm{kPa}$ of $1.3 \%$ SWCNTs with a good linear correlation (Pearson $=0.91)$. The increase in SWCNT concentration leads to a decrease in the failure strain: the pure gelatin-GP gel has a failure strain of $32.6 \pm 2,9 \%$, while it is reduced to almost one third $(13.9 \pm 3 \%)$ with $1.3 \% \mathrm{w} / \mathrm{w}$ SWCNT concentration: in this case, the Pearson coefficient is -0.89 . The elastic behaviour of the gelatin-SWCNT samples can be modelled using the Halpin-Tsai equations, which gave reasonable estimates for effective stiffness $E c$ (Table 1):

$$
\begin{gathered}
\frac{E_{c}}{E_{m}}=\frac{3}{8}\left[\frac{1+2(L / D) \eta_{L} V_{f}}{1-\eta_{L} V_{f}}\right]+\frac{5}{8}\left[\frac{1+2 \eta_{T} V_{f}}{1-\eta_{T} V_{f}}\right](1) \\
\eta_{L}=\frac{\left(E_{p} / E_{m}\right)-1}{\left(E_{p} / E_{m}\right)+2(L / D)}(2)
\end{gathered}
$$




$$
\eta_{T}=\frac{\left(E_{p} / E_{m}\right)-1}{\left(E_{p} / E_{m}\right)+2}(3)
$$

where $E m$ is the pure gelatin elastic modulus, $E p$ is the SWCNT elastic modulus, estimated around $500 \mathrm{GPa} .{ }^{17}$ The ratio between the length $L$ and the diameter $D$ of the SWCNT was set to $100 .{ }^{17-21}$ The $V f$ (final volume) is expressed using the dry mass of both gelatin and SWCNTs. ${ }^{21}$

\section{Electrical tests}

All the gelatin-SWCNT-GP samples show a capacitive behaviour, with a decrease of the modulus of the impedance as the frequency increases (Fig. $1 \mathrm{~d}, \mathrm{e})$

As the SWCNT concentration increase, the impedance decreases: this variation is more evident at low frequency. For instance, respect to the pure gelatin gel, at $1 \mathrm{kHz}$ the impedance decreases of $50 \%$ with just $0.3 \%$ SWCNT; at $1.3 \%$, the variation amount is $85 \%$. These decreases are linear correlated with the filler concentration, showing a Pearson coefficient of -0.85 .

\section{Cytotoxicity and cell growth}

Results of cytotoxicity test for the different gelatin-SWCNT scaffolds, reported in Fig. 2a, show cell viability $(98 \pm 3 \%)$ similar to negative control while cells treated with DMSO (positive control) presented a reduction of $80 \%$ in viability value. Scaffolds, presenting a viability value above $70 \%$, can be defined non cytotoxic. Taking in account results of impedance tests, cell growth test was performed. Cell growth analysis for differentiated cells (Fig. 2b) showed a slowing down at day 7 and a final value lower respect to control for both the differentiation protocols. Selected scaffolds' samples were cultured for 10 days. The test showed an initial reduction of cell viability (day 3) followed by its recovery and a final value similar to control (Fig. 2c). The final rate of colonization resulted satisfying on two gelatin-SWCNT scaffold typologies: $\mathrm{SWCNT}_{0.3 \%}$ and $\mathrm{SWCNT}_{0.9 \%}$.

\section{Immunohistochemistry}

Differentiated cells and scaffold were analyzed with immunohistochemical analysis to evaluate morphological changes through expression of myogenic- and cardiac-specific markers: Myogenin 
and MYL-2, respectively. The reduction of FBS concentration in $\mathrm{C}_{1 \%}$ samples produced the myogenic differentiation process, highlighted by elongated cell shape (Fig. 3a) and their fusion to form a myotubule and increased concentration of fluorescence signal in these cells, linked to augmented expression of Myogenin. RA-treated cells exhibited rather different morphological changes, typical of cardiac differentiation, with large and rounded multinucleated cells evidenced a fluorescence signal increase of MYL-2 in treated cells (Fig. 3b). Unfortunately, the strong background of scaffolds, generated by genipin used as cross-linker for their preparation, did not let to observe significant indications on scaffold-induced differentiation.

\section{Real-Time PCR analysis}

\section{Condition Assessment and selection of reference gene set}

After the optimization of the thermal-cycle profile of each designed PCR primer and adequate quantification of Real-time PCR efficiency, that resulted in the range of $95-105 \%$ with a linear standard curve greater than $|0.990|$ as reported in Table 2, the selected genes were run in each system analyzed: 1) $\mathrm{C}_{10 \%}+\mathrm{C}_{1 \%}+\mathrm{C}_{\mathrm{RA}}$; 2) $\mathrm{C}_{10 \%}+\mathrm{SWCNT}_{0.3 \%}+\mathrm{SWCNT}_{0.9 \%}$, The threshold cycle range resulted different among genes tested in a cell-specific manner. An example for the first system was reported in Fig. 4a. This analysis provided the gene expression stability measure (M) for each reference gene, which allowed ranking them from the least stable (higher $\mathrm{M}$ value) to the most stably expressed (lowest $\mathrm{M}$ value). Thus, ordering genes according to $\mathrm{M}$ values $(\mathrm{M}<1$ for heterogeneous groups) in the analyzed conditions, the rank was different depending on the cell system considered. In particular, the more stable genes for the first system $\mathrm{C}_{10 \%}+\mathrm{C}_{1 \%}+\mathrm{C}_{\mathrm{RA}}$ were YWHAG, UBC and PPIA (M=0.9) (Fig. 4b) while for the second one we chose only two reference genes, UBC and PPIA $(M=0.685)$. In fact, although we analysed nine reference genes for the $M$ value evaluation the stability was reached only with two genes $(\mathrm{M}=0.685)$ because the addition third gene created a destabilization of our system reaching high expression stability with M-value > of default limit $(\mathrm{M}=1.5)$. A similar behaviour was observed in previous study of our ${ }^{22,23}$ but unlike of this situation when the system was analysed with a specific software as NormFinder the three 
reference gene selected resulted not co-regulated despite the higher $M$ value while in the system $\mathrm{C}_{10 \%}+\mathrm{SWCNT}_{0.3 \%}+\mathrm{SWCNT}_{0.9 \%}$, also analyzing them with NormFinder the optimal setting resulted composed by two housekeeping.

Natriuretic and endothelin system mRNA expression levels in H9c2 cell line treated with FBS 1\% and retinoic acid

In order to evaluate cardiac phenotype, the NP and ET system were studied. As reported in Figure 5, a significantly increase of ANP, BNP and CNP was observed in $\mathrm{C}_{\mathrm{RA}}$ with respect to $\mathrm{C}_{10 \%}$ and $\mathrm{C}_{1 \%}$ as well as of their guanylate-cyclase receptors, NPR-A and NPR-B unlike the clearance receptor NPR-C resulted significantly decreased in $C_{R A}$. Furthermore, $C_{R A}$ revealed an increased expression of both ET-A and ET-B receptors in parallel with a decreased ET-1 levels with respect to $\mathrm{C}_{10 \%}$ and $\mathrm{C}_{1 \%}$ (Fig. 6). $\mathrm{CX}-43$, evaluated as a marker of cardiocytes proliferation and differentiation, resulted higher in $\mathrm{C}_{\mathrm{RA}}(1.096 \pm 0.49)$ with respect to both $\mathrm{C}_{10 \%}(0.785 \pm 0.12)$ and $\mathrm{C}_{1 \%}$ $(0.567 \pm 0.25)$ even though not significantly.

Natriuretic and endothelin system mRNA expression levels in gelatin-based scaffold at 0.3\% e $0.9 \%$ of SWCNT

In order to evaluate $\mathrm{H} 9 \mathrm{c} 2$ cell line growth and differentiation on SWCNT scaffolds, NP and ET systems mRNA expression were measured. NPs resulted decreased in $\mathrm{SWCNT}_{0.3 \%}$ and $\mathrm{SWCNT}_{0.9 \%}$ with respect to $\mathrm{C}_{10 \%}$ after 7 days of culture, mainly due to a lacking of complete differentiation in cardiac phenotype during these few days (Fig. 7 a-c). In parallel, a "down-regulation" of all receptor subtypes was observed in $\mathrm{SWCNT}_{0.3 \%}$ and $\mathrm{SWCNT}_{0.9 \%}$ with respect to the control group $\left(\mathrm{C}_{10 \%}\right)$ (Fig. 7 d, e).

As for NPs, mRNA expression levels of ET-1, ET-A and ET-B were lower in $\mathrm{SWCNT}_{0.3 \%}$ and $\mathrm{SWCNT}_{0.9 \%}$ with respect to $\mathrm{C}_{10 \%}$, while any statistical difference was observed between gelatinbased scaffold at 0.3/0.9 concentration of SWCNTs (Fig. 8).

CX-43, evaluated as a marker of myocytes differentiation during culture on CNT scaffold, was significantly decreased in $\mathrm{SWCNT}_{0.3 \%}$ and $\mathrm{SWCNT}_{0.9 \%}(0.15 \pm 0.06$ and $0.18 \pm 0.07$, respectively $)$ 
with respect to $\mathrm{C}_{10 \%}\left(0.76 \pm 0.1 ; \mathrm{p}=0.002 \mathrm{C}_{10 \%}\right.$ vs $\mathrm{SWCNT}_{0.3 \%}$ and $\mathrm{p}=0.007 \mathrm{C}_{10 \%}$ vs $\left.\mathrm{SWCNT}_{0.9 \%}\right)$, confirming a low growth/differentiation induced by CNT on this support.

\section{DISCUSSION}

The present study was finalized to evaluate new gelatin-based CNT supports useful for cardiac tissue engineering applications aiming at providing living, force-producing heart muscle tissue that might be transplanted on injured hearts. To date, the search for nanostructurable materials able to provide active support and interactions with biosystems at molecular and submolecular level is very active. In recent years, CNTs are certainly numbered among the most interesting and studied nanomaterials for a variety of applications. ${ }^{11,12}$ Here, we have developed scaffolds composed by gelatin (5\%) mixed with single-well carbon nanotubes (SWCNTs, $0.3 \%$ and $0.9 \%$ ), where a pool of H9c2 cell line was seeded. The H9c2 cell line is currently used as a gold standard in-vitro model since, due to its biochemical, morphological and electrical/hormonal signalling properties, it is able to mimic the behaviour of skeletal and cardiac muscle. ${ }^{24}$ A preliminary goal of the study was to evaluate any phenotypical changes of $\mathrm{H} 9 \mathrm{c} 2$ cell line, due to two different culture conditions: FBS reduction (from $10 \%$ to $1 \%$ ) and all-trans retinoic acid culture enrichment. ${ }^{24,25}$ In fact, one important feature of this cell line is its ability to differentiate from mono-nucleated myoblasts to myotubes when cultured in a low serum concentration media, getting an elongated shape and positioning in a parallel fashion. ${ }^{26}$ As expected, during the differentiation process in FBS reduction, H9c2 presented a skeletal muscle phenotype, as was evidenced by presence of Myogenin, a cell type-specific differentiation marker, while the addiction of RA to a $1 \%$ serum media induced a cardiac muscle phenotype, characterized by the overexpression of MYL-2. The differentiation of H9c2 cell, obtained with serum decrease and RA addition, led to a transcriptional up-regulation of genes involved in cardiac differentiation as NPs used as a marker for ventricular cardiomyocyte maturation. ${ }^{27-30}$ Moreover, a shift in the maturational phenotype of cultured cardiac cells is supported by measurement of steady state mRNA levels of the ET system that can be modulated 
during the differentiation into the cardiac phenotype exhibiting enhancing expression of both receptors in parallel to a decrease of ET-1 itself. Furthermore, CX-43 was also evaluated to confirm the results, since it is the only connexin known to be expressed in the working myocardium. The gap junction channels formed by CX-43 most likely have important roles during heart development. ${ }^{31}$ In our samples, CX-43 levels resulted higher in cell treated with retinoic acid with respect to both $\mathrm{C}_{10 \%}$ and $\mathrm{C}_{1 \%}$. These data provided the basis for the choice of $\mathrm{FBS} 10 \%$ as an optimal culture medium supplement for H9c2 cells on SWCNTs, instead of supplement with RA or depletion of FBS, in order to avoid confounding effect due to rapid cardiac differentiation or a more myogenic-like phenotype. In the second phases of our study, in order to increase the effect of the scaffold composites on cell phenotype changes, SWCNTs were incorporated into a natural polymer (gelatin), in presence of genipin, used as a cross-linker, which further increases proliferation, differentiation and electrical conductivity of cell seeded onto. The electric characterization showed that scaffolds with SWCNT concentration at $0.3 \%$ and $0.9 \%$ might be valid support providing an anchorage for cells on the scaffold surface, and stability for proliferation supporting the process of differentiation, elongation and electric conductivity. Despite of these good properties, the analysis of H9c2 cell growth curves showed a decrease in cell viability in the first 7 days of culture, probably due to the time required by those cells of adapting to the new material. Moreover, any changes were also observed in the mRNA expression of both NP and ET-1 systems neither in $\mathrm{SWCNT}_{0.3 \%}$ nor $\mathrm{SWCNT}_{0.9 \%}$ with respect to controls $\left(\mathrm{C}_{10 \%}\right)$.

A possible explanation could be a limited time of $\mathrm{H} 9 \mathrm{c} 2$ culture, not able to stimulate changes in the expression pattern of specific cardiac genes involved in the maturation process of a cardiomyocytelike phenotype. Furthermore, the transcription level of CX-43 resulted unchanged in SWCNTs at $0.3 \%$ and $0.9 \%$, underlining a lack of cell proliferation and migration ability.

Thus, the reduction of both proliferation rate and expression of the specific markers agree with previous reports investigating cardiomyocyte-like differentiation ${ }^{24,30-32}$ and were mainly accounted 
for a shift in cardiomyocyte maturational status that has not been yet occurred since $\mathrm{H} 9 \mathrm{c} 2$ required additional time to adapt to the scaffold.

Although further studies are needed, our data shown that SWCNTs conductive properties can potentially enhance cellular electrical excitability, leading to more mature cardiac phenotype in H9c2. On the other hand, the peculiar combination of mechanical strength with low electrical resistance and high thermal conductivity properties, makes SWCNTs good candidates for a wide variety of biomedical applications, in particular in cardiac tissue engineering.

\section{Conflicts of interest}

The authors confirm that there are no known conflicts of interest associated with this publication and there has been no significant financial support for this work that could have influenced its outcome.

\section{Funding}

This research did not receive any specific grant from funding agencies in the public, commercial, or not-for-profit sectors.

\section{Disclosure}

The authors have nothing to disclose and all of them have approved the final article version.

\section{References}

1. Townsend N, Wilson L, Bhatnagar P, Wickramasinghe K, Rayner M, Nichols M. Cardiovascular disease in Europe: epidemiological update 2016. Eur Heart J 2016;37:3232-3245.

2. Kirklin JK, Naftel DC, Kormos RL, Stevenson LW, Pagani FD, Miller MA, Baldwin JT, Young JB. The Fourth INTERMACS Annual Report: 4,000 implants and counting. J Heart Lung Transplant 2012;31:117-126.

3. Mehra MR, Kobashigawa J, Starling R, Russell S, Uber PA, Parameshwar J, Mohacsi P, Augustine S, Aaronson K, Barr M. Listing criteria for heart transplantation: International Society 
for Heart and Lung Transplantation guidelines for the care of cardiac transplant candidates_-2006. J Heart Lung Transplant 2006;25:1024-1042.

4. Dimmeler S, Burchfield J, Zeiher AM. Cell-based therapy of myocardial infarction. Arterioscler Thromb Vasc Biol 2008;2:208-216.

5. Bouten CV, Dankers PY, Driessen-Mol A, Pedron S, Brizard AM, Baaijens FP. Substrates for cardiovascular tissue engineering. Adv Drug Deliv Rev 2011;63:221-241.

6. Eschenhagen T, Zimmermann WH. Engineering Myocardial Tissue. Circ Res 2005;97:1220-1231

7. Borenstein JT, Weinberg EJ, Orrick BK, Sundback C, Kaazempur-Mofrad MR, Vacanti JP. Microfabrication of threedimensional engineered scaffolds. Tissue Eng 2007;13:1837-1844.

8. Hutmacher DW. Scaffold design and fabrication technologies for engineering tissues - State of the art and future perspectives. J Biomater Sci Polym 2001;12:107-124.

9. Ungerleider JL, Christman KL. Concise review: injectable biomaterials for the treatment of myocardial infarction and peripheral artery disease: translational challenges and progress. Stem Cells Transl Med 2014;3:1090-1099.

10. Zhou J, Chen J, Sun H, Qiu X, Mou Y, Liu Z, Zhao Y, Li X, Han Y, Duan C, Tang R, Wang C, Zhong W, Liu J, Luo Y, Mengqiu Xing M, Wang C. Engineering the heart: Evaluation of conductive nanomaterials for improving implant integration and cardiac function. Sci Rep $2014 ; 4: 3733$.

11. Martinelli V, Cellot G, Toma FM, Long CS, Caldwell JH, Zentilin L, Giacca M, Turco A, Prato M, Ballerini L, Mestroni L. Carbon-nanotubes instruct physiological growth and functionally mature syncytia: nongenetic engineering of cardiac myocytes. ACS Nano 2013;7:5746-5756.

12. Martinelli V, Cellot G, Toma FM, Long CS, Caldwell JH, Zentilin L, Giacca M, Turco A, Prato M, Ballerini L, Mestroni L. Carbon nanotubes promote growth and spontaneous electrical activity in cultured cardiac myocytes. Nano Lett 2012;12:1831-1838.

John Wiley \& Sons, Inc. 
13. Del Ry S, Cabiati M, Vozzi F, Battolla B, Caselli C, Forini F, Segnani C, Prescimone T, Giannessi D, Mattii L. Expression of C-type natriuretic peptide and its receptor NPR-B in cardiomyocytes. Peptides 2011;32:1713-1718.

14. Del Ry S, Cabiati M, Della Latta V, Zimbone S, Natale M, Lazzerini PE, Diciolla F, Capecchi PL, Laghi-Pasini F, Morales MA. Adenosine receptors expression in cardiac fibroblasts of patients with left ventricular dysfunction due to valvular disease. J Recept Signal Transduct Res 2016;3:17.

15. Bustin SA, Benes V, Garson JA, Hellemans J, Huggett J, Kubista M, Mueller R, Nolan T, Pfaffl MW, Shipley GL, Vandesompele J, Wittwer CT. The MIQE guidelines: minimum information for publication of quantitative real-time PCR experiments. Clin Chem 2009;55:611-622.

16. Vandesompele J, De Preter K, Pattyn F, Poppe B, Van Roy N, De Paepe A, Speleman F. Accurate normalization of real-time quantitative RT-PCR data by geometric averaging of multiple internal control genes. Genome Biol 2002;3:RESEARCH0034.

17. Gattazzo F, De Maria C, Whulanza Y, Taverni G, Ahluwalia A, Vozzi G. Realization and characterization of conductive hollow fibers for neuronal tissue engineering. J Biomed Mater Res B Appl Biomater 2015;103:1107-1119.

18. Coleman JN, Cadek M, Blake R, Nicolosi V, Ryan KP, Beltron C, Fonseca A, Nagy JB, Gunk'ko YK, Blau WJ. High Performance Nanotube-Reinforced Plastics: Understanding the Mechanism of Strength Increase. Advance Functional Mater 2004;14:791-798.

19. Kearns JC, Shambaugh RL. Polypropylene fibers reinforced with carbon nanotubes. J Appl Polym Sci 2002;86:2079-2084.

20. Putz KW, Mitchell CA, Krishnamoorti R, Green PF. Elastic modulus of single-walled carbon nanotube/poly (methyl methacrylate) nanocomposites. J Polym SCI Part B: Polym Phys $2004 ; 42: 2286-2293$.

John Wiley \& Sons, Inc. 
21. Jelen C, Mattei G, Montemurro F, De Maria C, Mattioli-Belmonte M, Vozzi G. Bone scaffolds with homogeneous and discrete gradient mechanical properties. Mater Sci Eng C Mater Biol Appl $2013 ; 33: 28-36$.

22. Cabiati M, Sabatino L, Caruso R, Caselli C, Prescimone T, Giannessi D, Del Ry S. Gene expression of C-type natriuretic peptide and of its specific receptor NPR-B in human leukocytes of healthy and heart failure subjects. Peptides 2012;37:240-246.

23. Sabatino L, Cabiati M, Caselli C, Del Ry S. Adenosine receptor expression and gene reference evaluation in human leukocytes. Clin Lab 2013;59:571-577.

24. Branco AF, Pereira SP, Gonzalez S, Gusev O, Rizvanov AA, Oliveira PJ. Gene Expression Profiling of H9c2 Myoblast Differentiation towards a Cardiac-Like Phenotype. PLoS One 2015;10:e0129303.

25. Comelli M, Domenis R, Bisetto E, Contin M, Marchin M, Ortolani F, Tomasetig L, Mavelli I. Cardiac differentation promotes mitochondrai development and ameliorates oxidative capacity in H9c2 cardiomyoblasts. Mitochondrion 2011;11:315-326.

26. Sardão VA, Oliveira PJ, Holy J, Oliveira CR, Wallace KB. Vital imaging of H9c2 myoblasts exposed to tert-butylhydroperoxide - characterization of morphological features of cell death. BMC Cell Biol 2007;8:11.

27. McGrath MF, de Bold AJ. Determinants of natriuretic peptide gene expression. Peptides 2005;26:933-943.

28. Rockwood DN, Akins RE Jr, Parrag IC, Woodhouse KA, Rabolt JF. Culture on electrospun polyurethane scaffolds decreases atrial natriuretic peptide expression by cardiomyocytes in vitro. Biomaterials 2008;9:4783-4791.

29. Weixin L, Yong L. Regulation of dHAND Protein Expression by All-Trans Retinoic Acid Through ET-1/ETAR Signaling in H9c2 Cells. J Cell Biochem 2006;99:478-484. 
30. Giusti L, Gargini C, Ceccarelli F, Bacci M, Italiani P, Mazzoni MR. Modulation of endothelin-A receptor, Galpha subunit, and RGS2 expression during H9c2 cardiomyoblast differentiation. J Recept Signal Transduct Res 2004;24:297-317.

31. You JO, Rafat M, Ye GJ, Auguste DT. Nanoengineering the Heart: Conductive Scaffolds Enhance Connexin 43 Expression. Nano Lett 2011;11:3643-3648.

32. Pereira SL, Ramalho-Santos J, Branco AF, Sardão VA, Oliveira PJ, Carvalho RA. Metabolic remodeling during $\mathrm{H} 9 \mathrm{c} 2$ myoblast differentiation: relevance for in vitro toxicity studies. Cardiovasc Toxicol 2011;11:180-190.

\section{Figure Legend}

Figure 1: Mechanical and electrical tests of gelatin-SWCNT-genepin samples. a) elastic modulus; b), failure stress; c) failure strain; d) Modulus and e) phase at different SWCNT concentration.

Figure 2: Assessment of cytotoxicity and cellular vitality. a) H9c2 cell line viability testing different gelatin-SWCNT-genepin concentrations $(0.3 \% ; 0.5 \% ; 0.7 \% ; 0.9 \%, 1.3 \%)$ with respect to Positive control (cells treated with DMSO 5\%) and negative control $\left(\mathrm{C}_{10 \%}\right)$; b) cell growth curves of system $1\left(\mathrm{C}_{10 \%}+\mathrm{C}_{1 \%}+\mathrm{C}_{\mathrm{RA}}\right)$ at different days of culture; c) cell growth curves of system 2 $\left(\mathrm{C}_{10 \%}+\mathrm{SWCNT}_{0.3 \%}+\mathrm{SWCNT}_{0.9 \%}\right)$ at different days of culture

Figure 3: H9c2 cells differentiation characterization. Representative images of the effect of serum (FBS) depletion and retinoic acid (RA) supplementation on H9c2 cell morphology. a) typical morphology of undifferentiated mononucleated and small spindle shaped myoblasts due to a FBS1\% evidenced by Myogenin; b) multinucleated and rounded cardiomyocytes due to concomitant addition of $50 \mathrm{nM}$ RA evidenced by MYL-2 
Figure 4: Selection of the optimal set of reference genes. a) $\mathrm{Ct}$ values range in $\mathrm{C}_{10 \%}+\mathrm{C}_{1 \%}+\mathrm{C}_{\mathrm{RA}}$. Each box consists of five horizontal lines displaying the 10th, 25th, 50th (median), 75th, and 90th percentiles of the variable. All values above the 90th percentile and below the 10th percentile are plotted separately. b) evaluation of reference gene expression stability (M-value) during stepwise exclusion of the least stable gene using GeNorm software.

Figure 5: Molecular characterization of $\mathrm{H} 9 \mathrm{c} 2$ cell line before and after the differentiation process by expression analysis of the natriuretic peptide system. Relative expression of a) ANP; b) BNP; c) CNP; d) NPR-A; e) NPR-B; f) NPR-C in $\mathrm{C}_{10 \%}+\mathrm{C}_{1 \%}+\mathrm{C}_{\mathrm{RA}}$.

[GRAPH LEGEND: $\mathrm{C}_{10 \%}$ : negative control, cells supplemented with 10\% FBS (white bar); $\mathrm{C}_{1 \%}$ : positive control 1, cells supplemented with $1 \%$ FBS, useful to evaluate potential myogenic differentiation (light grey); $\mathrm{C}_{\mathrm{RA}}$ : positive control 2, cells supplemented with $1 \%$ FBS and $50 \mathrm{nM}$ retinoic acid (black bar)]

Figure 6: Molecular characterization of $\mathrm{H} 9 \mathrm{c} 2$ cell line before and after the differentiation process by expression analysis of the endothelin system. Relative expression of a) Pre-proET-1; b) ET-A; c) ET-B in $\mathrm{C}_{10 \%}+\mathrm{C}_{1 \%}+\mathrm{C}_{\mathrm{RA}}$. [GRAPH LEGEND: $\mathrm{C}_{10 \%}$ : negative control, cells supplemented with 10\% FBS (white bar); $\mathrm{C}_{1 \%}$ : positive control 1, cells supplemented with $1 \%$ FBS, useful to evaluate potential myogenic differentiation (light grey); $\mathrm{C}_{\mathrm{RA}}$ : positive control 2, cells supplemented with 1\% FBS and $50 \mathrm{nM}$ retinoic acid (black bar)]

Figure 7: Molecular characterization of gelatin-single walled nanotubes (SWCNT)-genepin scaffolds by expression analysis of the natriuretic peptide system. Relative expression of a) ANP; b) $\mathrm{BNP}$; c) $\mathrm{CNP}$; d) NPR-A; e) NPR-B; f) NPR-C in $\mathrm{C}_{10 \%}+\mathrm{SWCNT}_{0.3 \%}+\mathrm{SWCNT}_{0.9 \%}$. [GRAPH LEGEND: $\mathrm{C}_{10 \%}$ : negative control, cells supplemented with 10\% FBS (white bar); $\mathrm{C}_{0.3 \%}$ : positive control 1, cells supplemented with $1 \% \mathrm{FBS}$, useful to evaluate potential myogenic differentiation (light grey); $\mathrm{C}_{\mathrm{RA}}$ : positive control 2, cells supplemented with 1\% FBS and $50 \mathrm{nM}$ retinoic acid (black bar)]

Figure 8: Molecular characterization of gelatin-single walled nanotubes (SWCNT)-genepin scaffolds by expression analysis of the endothelin system. Relative expression of a) Pre-proET-1; b) ET-A; c) ET-B in $\mathrm{C}_{10 \%}+\mathrm{SWCNT}_{0.3 \%}+\mathrm{SWCNT}_{0.9 \%}$. 
1

2

3

4

5

6

7

8

9

10

11

12

13

14

15

16

17

18

19

20

21

22

23

24

25

26

27

28

29

30

31

32

33

34

35

36

37

38

39

40

41

42

43

44

45

46

47

48

49

50

51

52

53

54

55

56

57

58

59

60

[GRAPH LEGEND: $\mathrm{C}_{10 \%}$ : negative control, cells supplemented with 10\% FBS (white bar); $\mathrm{C}_{1 \%}$ : positive control 1, cells supplemented with $1 \%$ FBS, useful to evaluate potential myogenic differentiation (light grey); $\mathrm{C}_{\mathrm{RA}}$ : positive control 2 , cells supplemented with 1\% FBS and $50 \mathrm{nM}$ retinoic acid (black bar)]

John Wiley \& Sons, Inc. 
Table 1: samples elastic modulus $(E c)$ expresses as percentage of the pure gelatingenepin matrix $(\mathrm{Em})$. The model error is calculated as "Experiment" minus "Model".

\begin{tabular}{|c|c|c|c|}
\hline \multirow{2}{*}{$\begin{array}{c}\text { SWCNT } \\
\text { Concentration (\%) }\end{array}$} & \multicolumn{2}{|c|}{ Ec/Em (\%) } & \multirow{2}{*}{$\begin{array}{c}\text { Model error } \\
\text { (\%) }\end{array}$} \\
\cline { 2 - 4 } & Experiment & Model & 5 \\
\hline 0.3 & 118 & 123 & 1 \\
\hline 0.5 & 140 & 139 & 6 \\
\hline 0.7 & 160 & 154 & 7 \\
\hline 0.9 & 177 & 170 & 10 \\
\hline 1.3 & 189 & 200 & \\
\hline
\end{tabular}




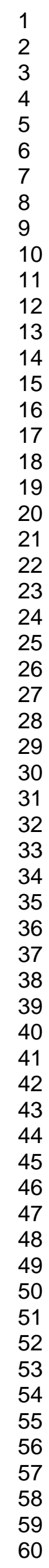

60

John Wiley \& Sons, Inc. 
Table 2: Primer sequence details of the analyzed gene

\begin{tabular}{|c|c|c|c|c|c|c|c|}
\hline GENE & PRIMER SEQUENCE & $\begin{array}{l}\text { GENBANK, } \\
\text { ACCESSION \# }\end{array}$ & LOCATION & $\begin{array}{l}\text { AMPLICON } \\
\text { LENGHT, bp }\end{array}$ & $\begin{array}{l}\text { TEMPERATURE, } \\
{ }^{\circ} \mathrm{C}\end{array}$ & $\begin{array}{c}\text { EFFICIENCY, } \\
\%\end{array}$ & $\mathbf{R}^{2}$ \\
\hline АCTB & $\begin{array}{l}\text { F: GTCGTACCACTGGCATTGTG } \\
\text { R:CTCTCAGCTGTGGTGGTGAA }\end{array}$ & NM_031144 & $\operatorname{chr} 12 \mathrm{p} 11$ & 181 & 60 & $104.3 \%$ & 0.998 \\
\hline GAPDH & $\begin{array}{l}\text { F: CTACCCACGGCAAGTTCAAC } \\
\text { R: CCAGTAGACTCCACGACATAC }\end{array}$ & NM_017008 & $\operatorname{chr} 4 \mathrm{q} 42$ & 98 & 60 & $98.4 \%$ & 0.999 \\
\hline GUSB & $\begin{array}{l}\text { F: ATCCCGGCCAGCATGTCCCCAAG } \\
\text { R: GTTCCCGCGAAGGGGTCTCCT }\end{array}$ & NM_017015 & $\operatorname{chr} 12 \mathrm{q} 12$ & 124 & 60 & $100.2 \%$ & 0.999 \\
\hline PPIA & $\begin{array}{l}\text { F: CCAAACACAAATGGTT } \\
\text { R: ATTCCTGGACCCAAAACGCT }\end{array}$ & NM_017101 & $\operatorname{chr} 14 q 21$ & 100 & 60 & $98.4 \%$ & 0.998 \\
\hline RPL-13A & $\begin{array}{l}\text { F: GGATCCCTCCACCCTATGACA } \\
\text { R: CTGGTACTTCCACCCGACCTC }\end{array}$ & NM_173340.2 & chr 1q22 & 130 & 60 & $101 \%$ & 0.999 \\
\hline SDHA & $\begin{array}{l}\text { F: CTCTTTTGGACCTTGTCGTCTTT } \\
\text { R: TCTCCAGCATTTGCCTTAATCGG }\end{array}$ & NM_130428 & chr $1 \mathrm{p} 11$ & 102 & 60 & 104.7 & 0.999 \\
\hline ТВР & $\begin{array}{l}\text { F: CACCGTGAATCTTGGCTGTAAAC } \\
\text { R: CGCAGTTGTTCGTGGCTCTC }\end{array}$ & NM_001004198 & chr 1q12 & 123 & 60 & 105 & 0.998 \\
\hline UBC & $\begin{array}{l}\text { F: ATCTAGAAAGAGCCCTTCTTGTGC } \\
\text { R: ACACCTCCCCATCAAACCC }\end{array}$ & NM_017314.1 & $\operatorname{chr} 12 \mathrm{q} 15$ & 50 & 60 & $95 \%$ & 0.997 \\
\hline YWHAG & $\begin{array}{l}\text { F: TTCCTAAAGCCCTTCAAGGCA } \\
\text { R: GGCTTTCTGCACTAGTTGCTCG }\end{array}$ & NM_019376.2 & $\operatorname{chr} 12 \mathrm{q} 12$ & 100 & 60 & $95.3 \%$ & 0.997 \\
\hline ANP & $\begin{array}{l}\text { F: AAGTGTAGATGAGTGGTT } \\
\text { R: TGGTGCTGAAGTTTATTC }\end{array}$ & NM_012612 & $\operatorname{chr} 5 \mathrm{q} 36$ & 118 & 58 & 95.3 & 0.999 \\
\hline BNP & $\begin{array}{l}\text { F: ATCTGTCGCCGCTGGGAGGT } \\
\text { R: TGGATCCGGAAGGCGCTGTCT }\end{array}$ & NM_173340 & chr 1q22 & 130 & 60 & 101 & 0.999 \\
\hline CNP & $\begin{array}{l}\text { F: GGAGCCAATCTCAAGGGA } \\
\text { R: TGCCGCCTTTGTATTTGC }\end{array}$ & NM_053750 & $\operatorname{chr} 9 \mathrm{q} 35$ & 70 & 60 & 105 & 0.998 \\
\hline NPR-A & $\begin{array}{l}\text { F: AGAGCCTGATAATCCTGAGTA } \\
\text { R: A TCCACGGTGAAGTTGAAC }\end{array}$ & NM_012613 & $\operatorname{chr} 2 \mathrm{q} 34$ & 81 & 58 & 95.4 & 0.998 \\
\hline NPR-B & $\begin{array}{l}\text { F: CCCATCCTGTGATAAAACTCC } \\
\text { R: AAGCTGGAAACACCAAACA } \\
\end{array}$ & NM_053838 & $\operatorname{chr} 2 \mathrm{q} 16$ & 89 & 60 & 104 & 0.999 \\
\hline NPR-C & $\begin{array}{l}\text { F: GGACCGCGAAGCCTGAGTTTGAGA } \\
\text { R: ATGGACACCTGCCCGGCGATACCT }\end{array}$ & NM_012868 & chr 9q35 & 240 & 64 & 100.3 & 0.998 \\
\hline Pre-proET-1 & $\begin{array}{l}\text { F: GTCTAAGCGATCCTTGAA } \\
\text { R: AATTCCAGCACTTCTTGT } \\
\end{array}$ & NM_012548 & chr $17 \mathrm{p} 12$ & 98 & 58 & 96 & 0.997 \\
\hline ET-A & $\begin{array}{l}\text { F: CTCCACAGTAGTAGCACAT } \\
\text { R: TAGCCAGTCCTCACAGTA }\end{array}$ & NM_012550 & $\operatorname{chr} 19 q 11$ & 75 & 60 & 95 & 0.997 \\
\hline ET-B & $\begin{array}{l}\text { F: GATACGACAACTTCCGCTCCA } \\
\text { R: GTCCACGATGAGGACAATGAG }\end{array}$ & NM_017333 & $\operatorname{chr} 15 \mathrm{q} 21-\mathrm{q} 22$ & 85 & 64 & 101 & 0.990 \\
\hline CX-43 & $\begin{array}{l}\text { F: CTCAACAACCTGGCTGCGAAA } \\
\text { R: GGTGGGCACAGACACGAATAT }\end{array}$ & NM_012567.2 & chr 20q11 & 60 & 60 & 103.2 & 0.998 \\
\hline
\end{tabular}


Table legend. ACTB: beta-actin; GAPDH: glyceraldehyde-3-phosphate dehydrogenase; GUSB: glucuronidase, beta; PPIA: peptidylprolyl isomerase a (cyclophilin a); RPL13: ribosomal protein 113a; SDHA: succinate dehydrogenase complex, subunit a, flavoprotein; TBP: tata binding protein; UBC: ubiquitin C; YWHAG: tyrosine 3monooxygenase/tryptophan 5-monooxygenase activation protein, gamma polypeptide; ANP: atrial natriuretic peptide; BNP: B-type (or brain) natriuretic peptide; CNP: C-type natriuretic peptide; NPR-A: Natriuretic peptide receptor A; NPR-B: Natriuretic peptide receptor B; NPR-C: Natriuretic peptide receptor C or clearance receptor; Pre-proET-1: endothelin 1 gene; ET-A: endothelin receptor A; ET-B: endothelin receptor B; CX-43: connexin-43 

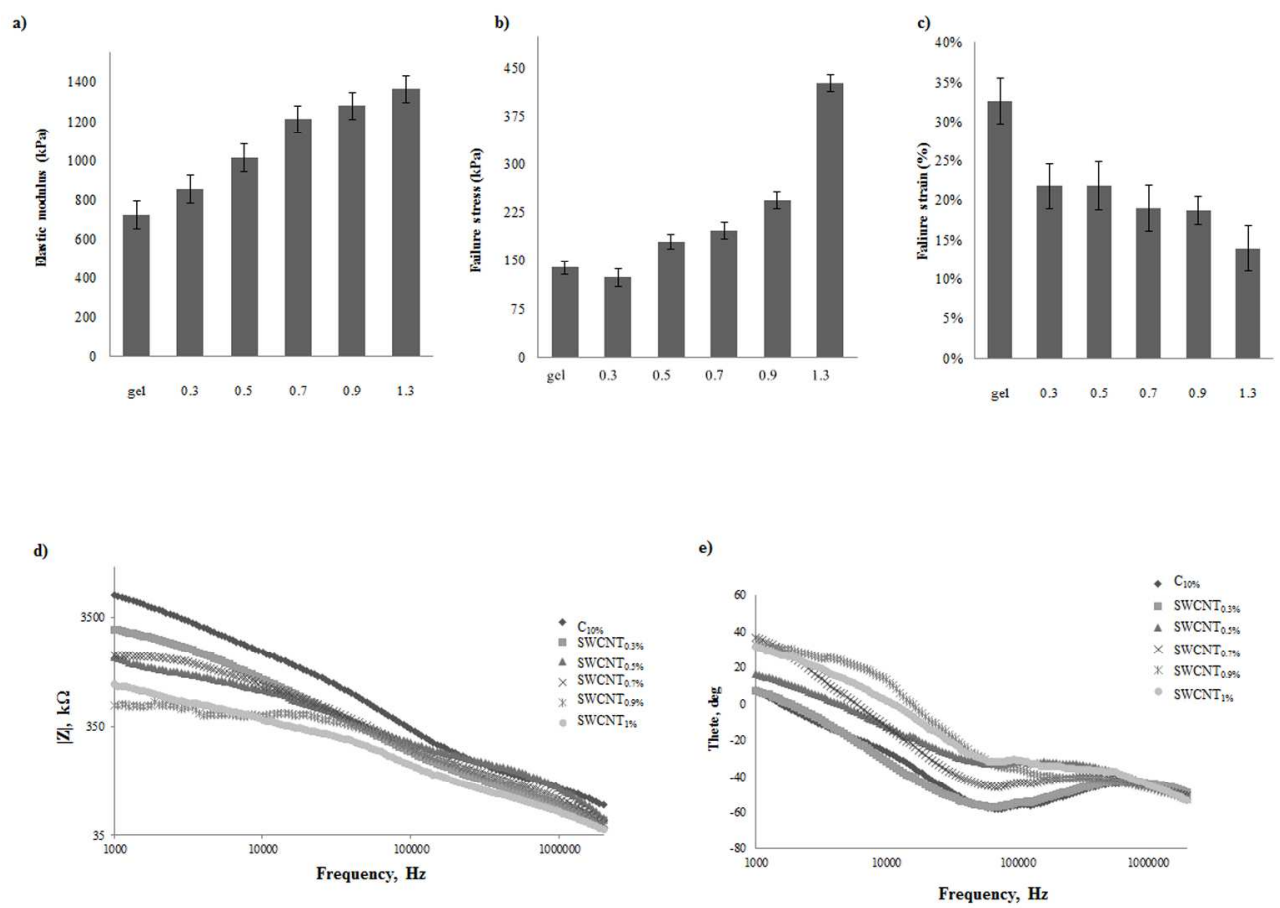

Figure 1: Mechanical and electrical tests of gelatin-SWCNT-genepin samples. a) elastic modulus; b), failure stress; c) failure strain; d) Modulus and e) phase at different SWCNT concentration.

$411 \times 287 \mathrm{~mm}(300 \times 300 \mathrm{DPI})$

John Wiley \& Sons, Inc. 


\begin{abstract}
a)
\end{abstract}

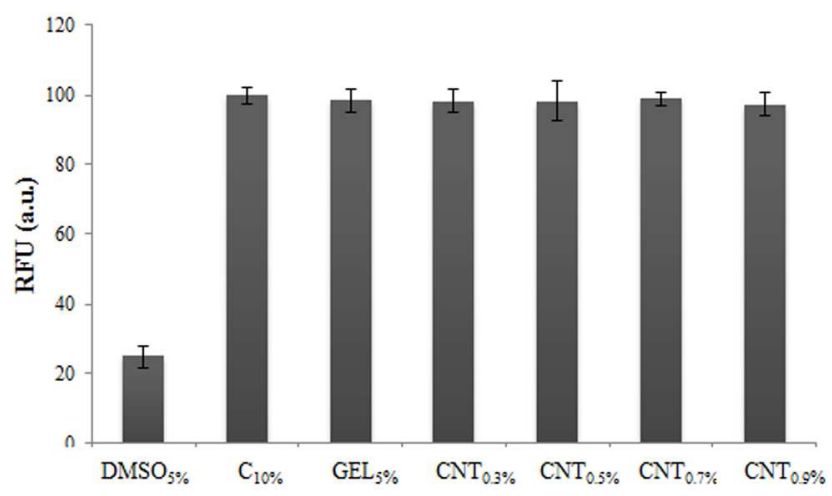

b)

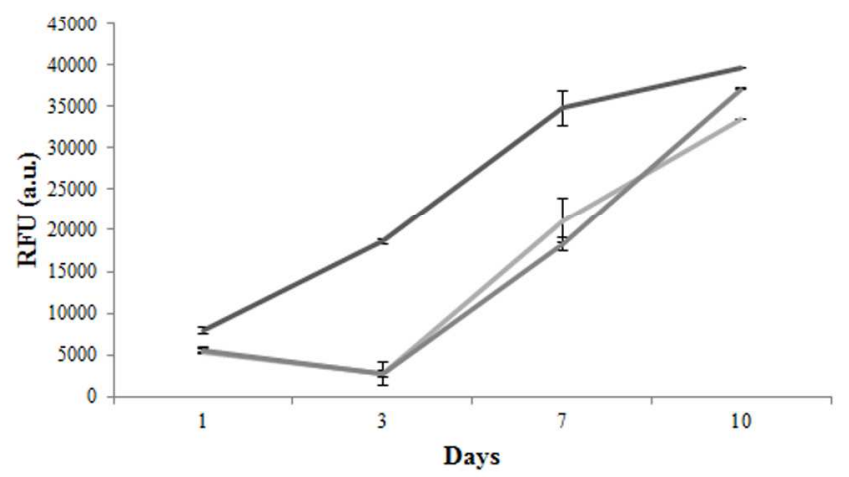

c)

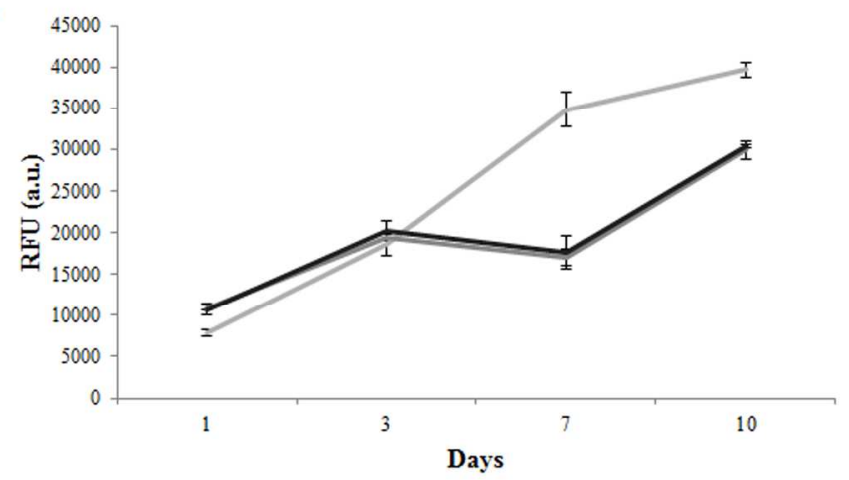

Figure 2: Assessment of cytotoxicity and cellular vitality. a) H9c2 cell line viability testing different gelatinSWCNT-genepin concentrations $(0.3 \% ; 0.5 \% ; 0.7 \% ; 0.9 \%, 1.3 \%)$ with respect to Positive control (cells treated with DMSO $5 \%$ ) and negative control (C10\%); b) cell growth curves of system 1 $(\mathrm{C} 10 \%+\mathrm{C} 1 \%+\mathrm{CRA})$ at different days of culture; c) cell growth curves of system 2 (C10\%+SWCNT0.3\%+SWCNT0.9\%) at different days of culture

$196 \times 334 \mathrm{~mm}(300 \times 300 \mathrm{DPI})$

John Wiley \& Sons, Inc. 
a)

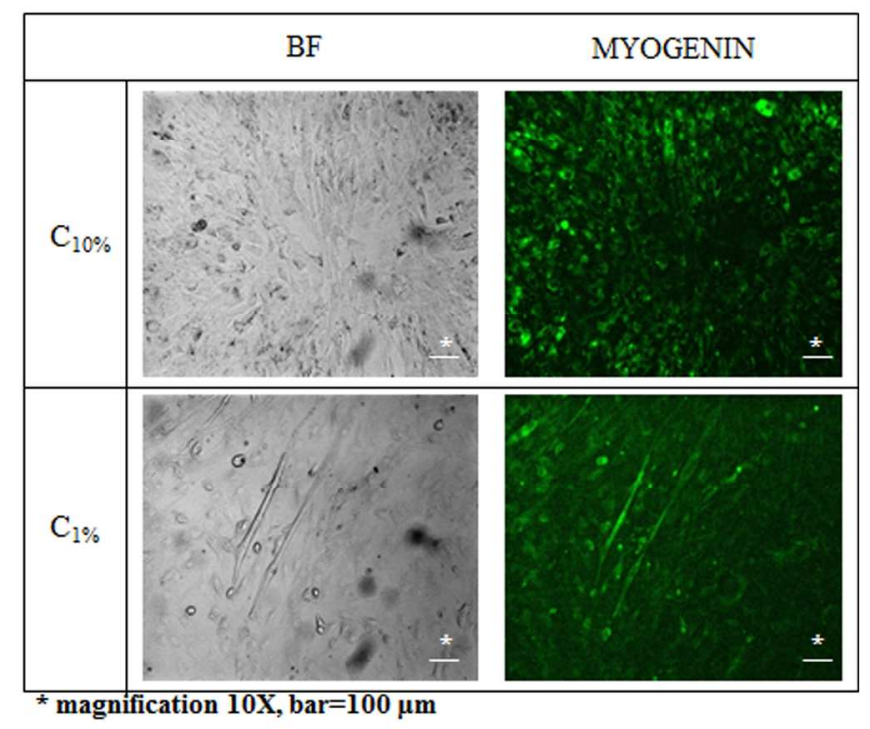

b)

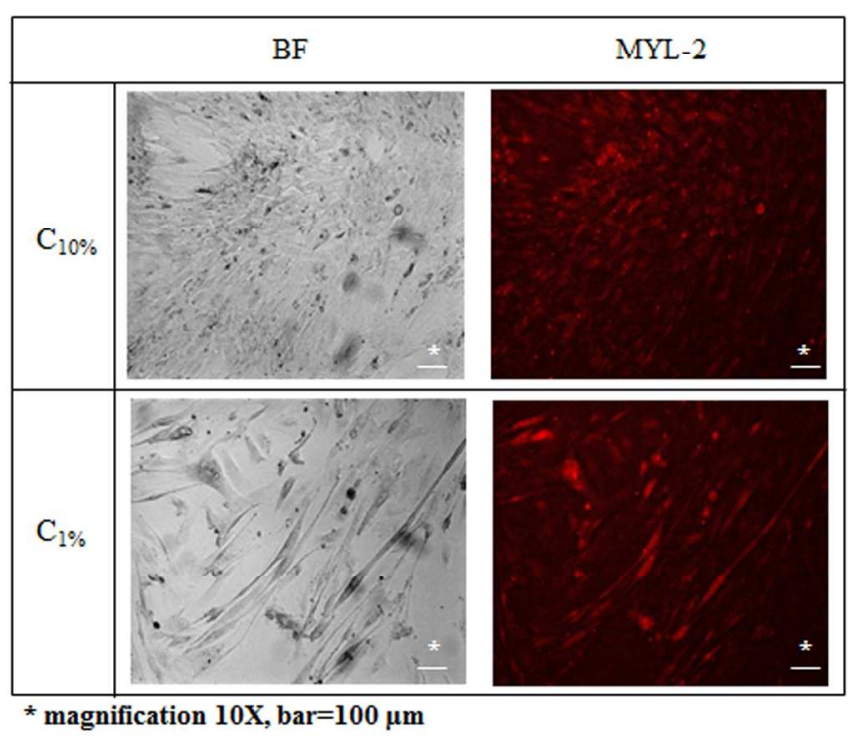

Figure 3: H9c2 cells differentiation characterization. Representative images of the effect of serum (FBS) depletion and retinoic acid (RA) supplementation on H9c2 cell morphology. a) typical morphology of undifferentiated mononucleated and small spindle shaped myoblasts due to a FBS $1 \%$ evidenced by Myogenin; b) multinucleated and rounded cardiomyocytes due to concomitant addition of $50 \mathrm{nM}$ RA evidenced by MYL-2

$182 \times 290 \mathrm{~mm}(300 \times 300$ DPI $)$ 
a)

b)
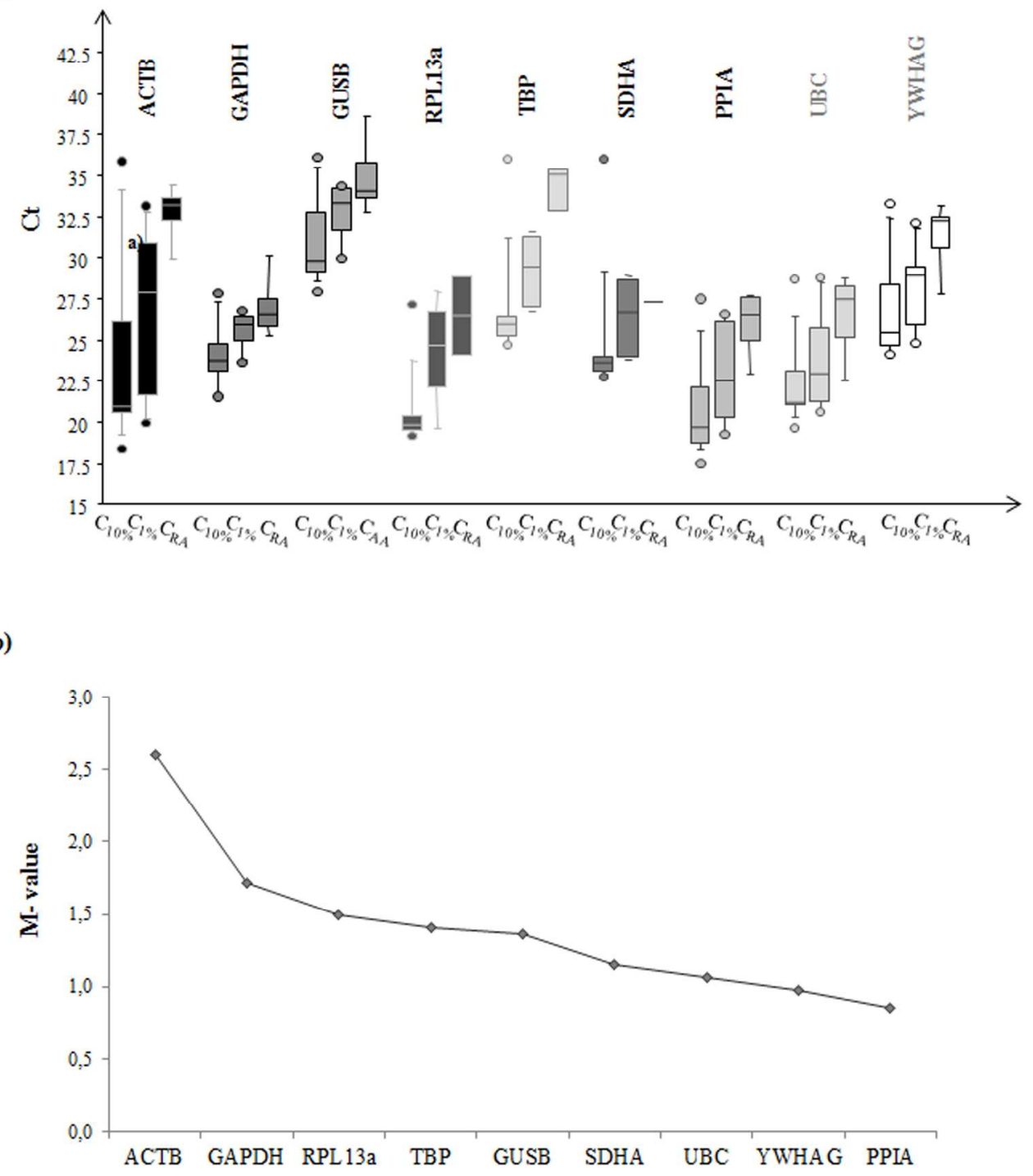

Figure 4: Selection of the optimal set of reference genes. a) Ct values range in $\mathrm{C} 10 \%+\mathrm{C} 1 \%+\mathrm{CRA}$. Each box consists of five horizontal lines displaying the 10th, 25th, 50th (median), 75th, and 90th percentiles of the variable. All values above the 90th percentile and below the 10th percentile are plotted separately. b) evaluation of reference gene expression stability (M-value) during stepwise exclusion of the least stable gene using GeNorm software

$235 \times 278 \mathrm{~mm}(300 \times 300 \mathrm{DPI})$

John Wiley \& Sons, Inc. 

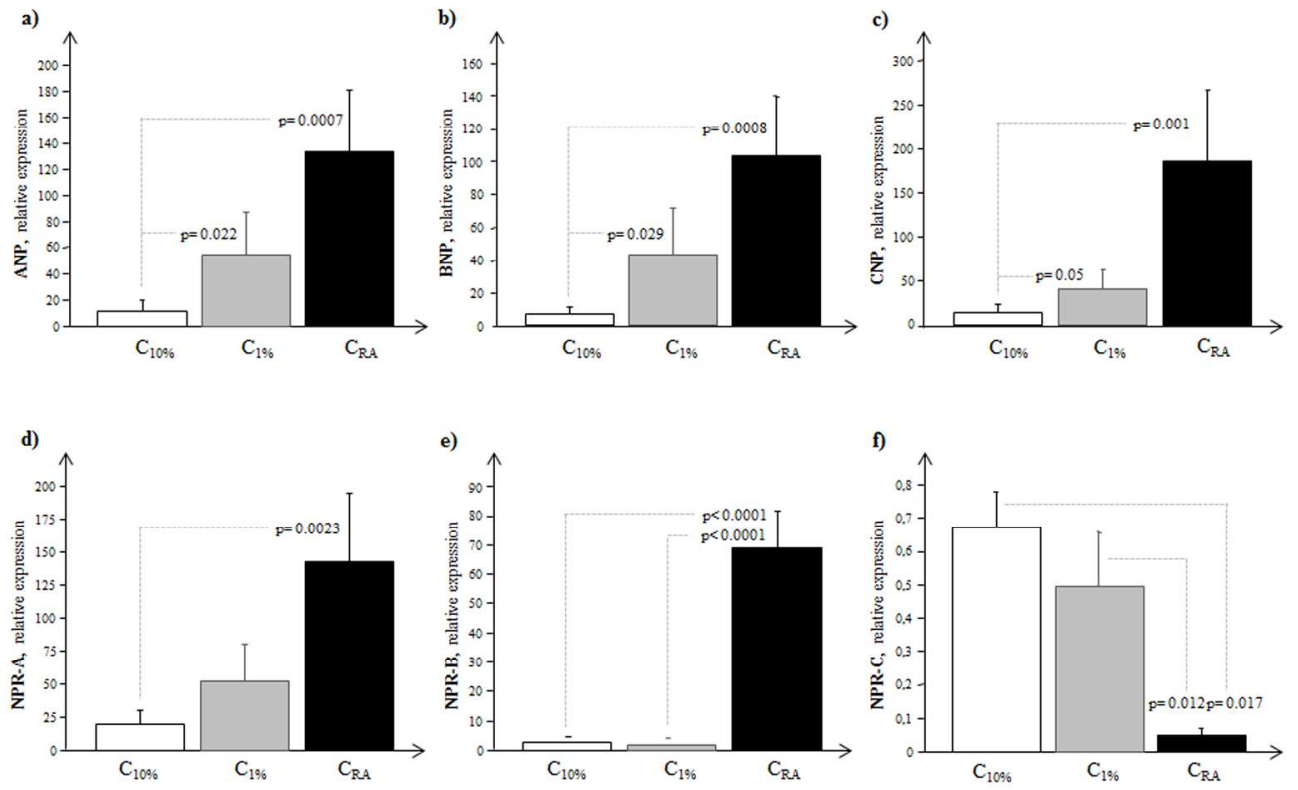

Figure 5: Molecular characterization of $\mathrm{H} 9 \mathrm{c} 2$ cell line before and after the differentiation process by expression analysis of the natriuretic peptide system. Relative expression of a) ANP; b) BNP; c) CNP; d) NPR-A; e) NPR-B; f) NPR-C in C $10 \%+C 1 \%+C R A$.

[GRAPH LEGEND: C10\%: negative control, cells supplemented with 10\% FBS (white bar); C1\%: positive control 1 , cells supplemented with $1 \%$ FBS, useful to evaluate potential myogenic differentiation (light grey); CRA: positive control 2, cells supplemented with 1\% FBS and $50 \mathrm{nM}$ retinoic acid (black bar)]

$$
333 \times 204 \mathrm{~mm}(300 \times 300 \text { DPI })
$$


b)
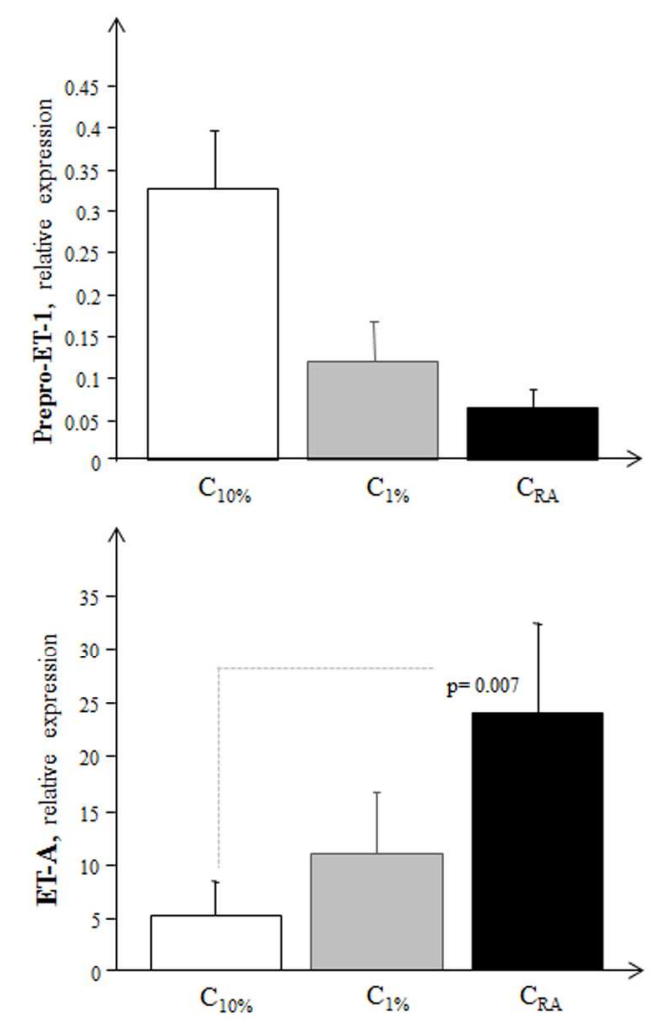

c)

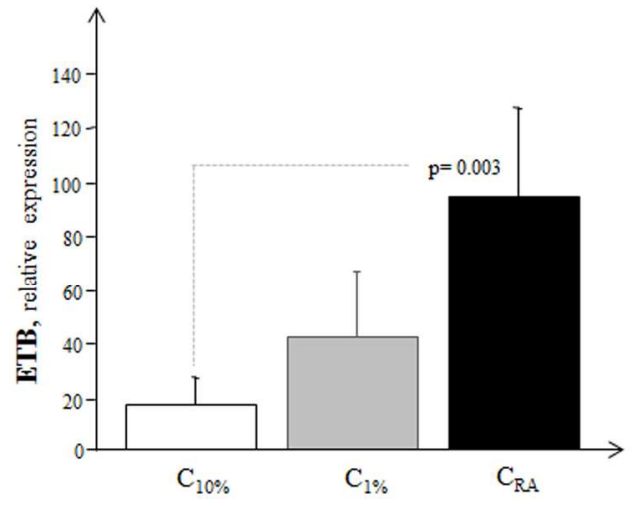

Figure 6: Molecular characterization of $\mathrm{H} 9 \mathrm{c} 2$ cell line before and after the differentiation process by expression analysis of the endothelin system. Relative expression of a) Pre-proET-1; b) ET-A; c) ET-B in $\mathrm{C} 10 \%+\mathrm{C} 1 \%+$ CRA.

[GRAPH LEGEND: C10\%: negative control, cells supplemented with 10\% FBS (white bar); C1\%: positive control 1 , cells supplemented with $1 \%$ FBS, useful to evaluate potential myogenic differentiation (light grey); CRA: positive control 2, cells supplemented with 1\% FBS and 50 nM retinoic acid (black bar)]

$$
151 \times 334 \mathrm{~mm}(300 \times 300 \mathrm{DPI})
$$



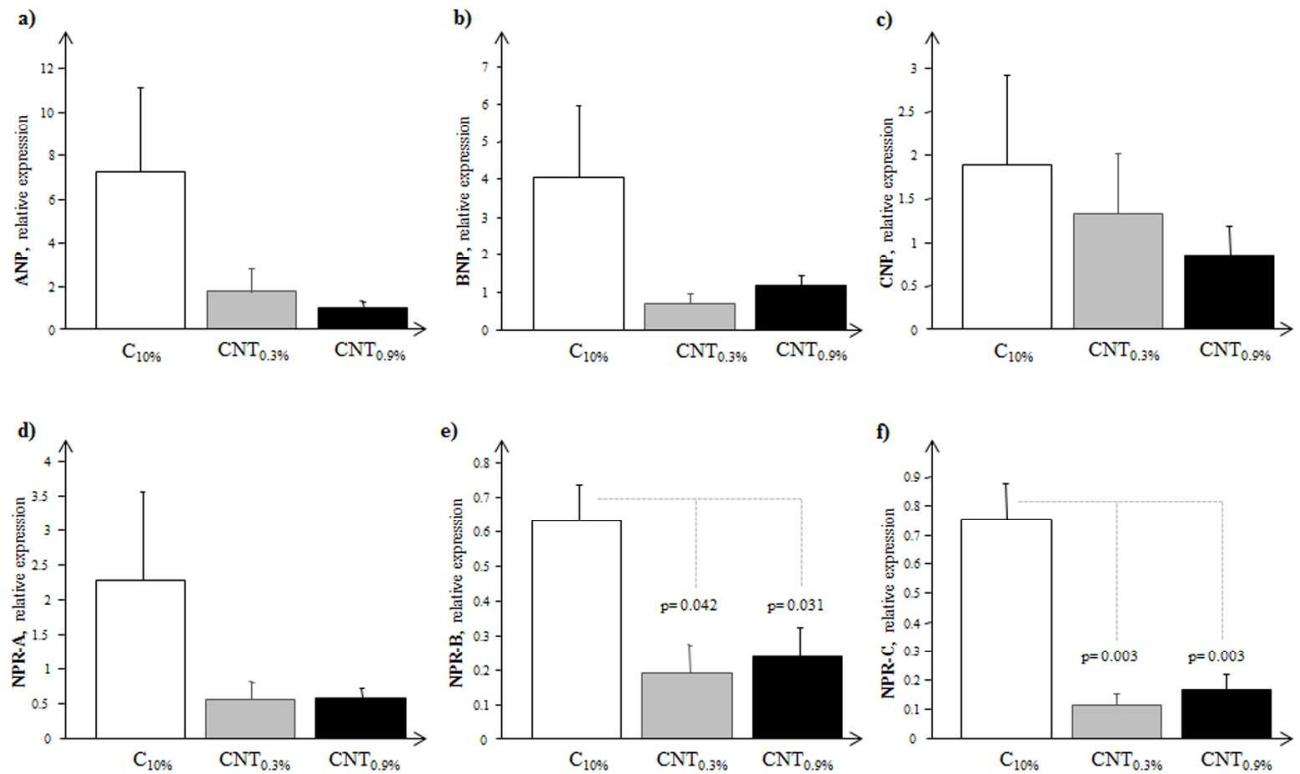

Figure 7: Molecular characterization of gelatin-single walled nanotubes (SWCNT)-genepin scaffolds by expression analysis of the natriuretic peptide system. Relative expression of a) ANP; b) BNP; c) CNP; d) NPR-A; e) NPR-B; f) NPR-C in C10\%+SWCNT0.3\%+ SWCNT0.9\%.

[GRAPH LEGEND: C10\%: negative control, cells supplemented with $10 \%$ FBS (white bar); C0.3\%: positive control 1 , cells supplemented with $1 \%$ FBS, useful to evaluate potential myogenic differentiation (light grey); CRA: positive control 2, cells supplemented with $1 \%$ FBS and $50 \mathrm{nM}$ retinoic acid (black bar)]

$330 \times 201 \mathrm{~mm}(300 \times 300 \mathrm{DPI})$

John Wiley \& Sons, Inc. 
b)

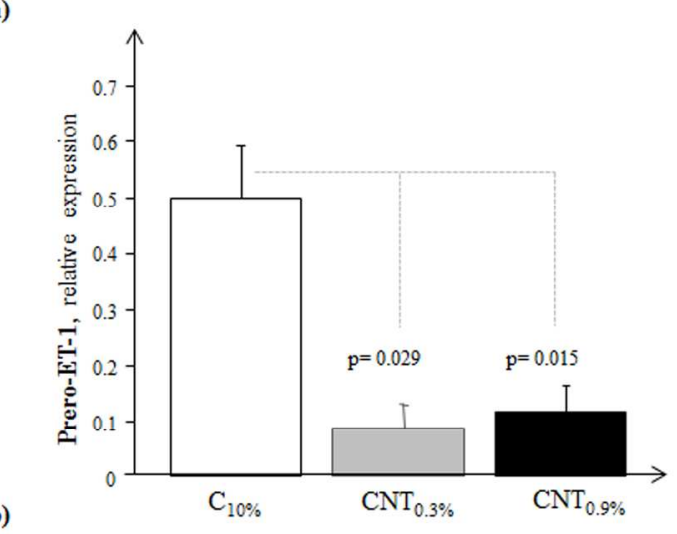

c)
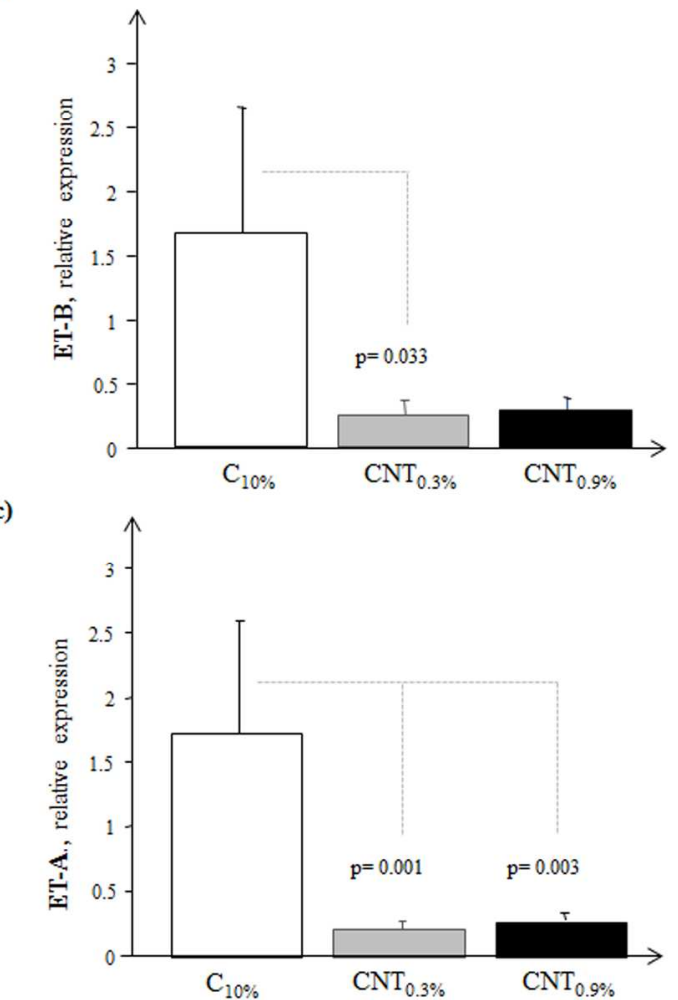

Figure 8: Molecular characterization of gelatin-single walled nanotubes (SWCNT)-genepin scaffolds by expression analysis of the endothelin system. Relative expression of a) Pre-proET-1; b) ET-A; c) ET-B in C $10 \%+$ SWCNT0.3\%+ SWCNT0.9\%.

[GRAPH LEGEND: C10\%: negative control, cells supplemented with 10\% FBS (white bar); C1\%: positive control 1 , cells supplemented with $1 \%$ FBS, useful to evaluate potential myogenic differentiation (light grey); CRA: positive control 2, cells supplemented with 1\% FBS and $50 \mathrm{nM}$ retinoic acid (black bar)]

$$
151 \times 334 \mathrm{~mm}(300 \times 300 \mathrm{DPI})
$$

